\title{
PENGARUH VARIASI RASIO HAF/SRF TERHADAP SIFAT VULKANISAT NBR
}

\section{(THE EFFECT OF HAF/SRF RATIO ON PROPERTIES OF NBR VULCANIZATES)}

\author{
Ihda Novia Indrajati, Indiah Ratna Dewi, Dodi Irwanto \\ Balai Besar Kulit, Karet dan Plastik, Yogyakarta \\ Email: ihdanovia@gmail.com
}

Diterima: 5 September 2012 Direvisi: 5 November 2012 Disetujui: 4 Desember 2012

\begin{abstract}
The objectives of the research were to study the effect of HAF/SRF black ratio and the loading of sulfur on vulcanization characteristic, swelling behaviour and compression set of NBR vulcanizates. The ratio of HAF/SRF were 0/70; 10/60; 20/50; 30/40; 35/35; 40/30; 50/20 and 70/0 phr, respectively. The observation of this research consist of curing characteristic, morphology property and swelling equilibrium. Curing characteristic was determined from cure rate index (CRI), vulcanizates morphology was studied by SEM and swelling equilibrium was conducted by immersion test using benzene. The data were analyzed qualitatively to see the respond of the variable on physical properties. The curing characteristic of double filler vulcanizates was higher than those with single filler. Solvent uptake for double filler present in between to those with HAF or SRF. All of vulcanizates indicate the anomalous mass tranfer, with $n>0,5$ and constant $k$ showed the same trend. The intrinsic diffusivity ( $\left.D^{*}\right)$, sorption and permeation coefficient showed similar trend and the maximum was obtained by the ratio $H A F / S R F 0 / 70$.
\end{abstract}

Keywords: NBR, HAF/SRF, vulcanization characteristic, swelling, mass transfer

\begin{abstract}
ABSTRAK
Tujuan penelitian adalah mempelajari pengaruh rasio HAF/SRF terhadap karakteristik vulkanisat, kesetimbangan swelling dan perpindahan massa pada vulkanisat NBR. Rasio HAF/SRF yang digunakan berturut - turut $0 / 70 ; 10 / 60 ; 20 / 50 ; 30 / 40 ; 35 / 35 ; 40 / 30 ; 50 / 20$ dan 70/0 phr. Pengamatan dilakukan pada karakteristik vulkanisasi, sifat morfologi dan kesetimbangan swelling. Data dianalisa secara kualitatif untuk melihat respon variabel penelitian terhadap sifat fisis vulkanisat. Karakteristik vulkanisasi ditentukan dari nilai indeks kecepatan vulkanisasi (cure rate index/CRI), morfologi vulkanisat dipelajari menggunakan alat SEM, dan kesetimbangan swelling dilakukan dengan cara perendaman dalam benzen dengan menghitung kecepatan penetrasi dan koefisien difusinya. Karakteristik vulkanisasi vulkanisat bahan pengisi ganda memberikan nilai lebih tinggi daripada dengan bahan pengisi tunggal. Konsumsi pelarut (uptake) vulkanisat dengan bahan pengisi HAF dan SRF mempunyai nilai berada diantara vulkanisat dengan bahan pengisi tunggal. Mekanisme perpindahan massa untuk keseluruhan rasio HAF/SRF mengindikasikan anomali dengan nilai $n>0,5$ dan konstanta $k$ yang relatif sama. Koefisien difusi intrinsik $\left(D^{*}\right)$, koefisien serapan (S) dan koefisien permeasi (P) secara umum menunjukkan kecenderungan dan nilai maksimum diberikan oleh rasio 0/70.
\end{abstract}

Kata kunci: NBR, HAF/SRF, karakteristik vulkanisasi, swelling, perpindahan massa 


\section{PENDAHULUAN}

Nitrile Butadiene Rubber (NBR) banyak digunakan oleh industri otomotif karena mempunyai ketahanan terhadap bahan bakar, oli dan fluida lainnya. NBR mempunyai struktur rantai nonreguler (amorf), sehingga tidak mengkristal ketika diregangkan. Konsekuensinya NBR tidak mempunyai sifat penguatan internal (self reinforced), maka untuk meningkatkan sifat-sifat pelarut maupun mekanik perlu ditambah bahan pengisi yang bersifat menguatkan (reinforcing filler) atau mencampur NBR dengan karet jenis lain. Namun demikian, NBR mempunyai ketahanan terhadap cuaca (weathering) dan ozon yang rendah (Barlow, 1993; Jovanović, et.al., 2009, Manoj, et.al., 2011). Sifat ketahanan NBR terhadap oli sangat dipengaruhi oleh kandungan acrylonitrile (ACN). Makin tinggi kandungan ACNnya, maka NBR jenis tersebut makin tahan terhadap oli.

Carbon black (CB) telah diketahui dapat digunakan sebagai bahan pengisi penguat (reinforcing) untuk NBR. Jenis "Semi Reinforcing Furnace" (SRF) black dilaporkan dapat memberikan kekuatan yang cukup dengan harga relatif rendah (Franta, 1989). Penelitian penggunaan berbagai jenis $\mathrm{CB}$ pada NBR maupun campuran NBR dengan karet lain telah banyak dilakukan. Manoj, et.al. (2011) mempelajari karakteristik curing, perilaku swelling dan sifat-sifat mekanik sistem NBR/EPDM dengan bahan pengisi CB jenis Intermediate Sub Abrasi Furnace (ISAF), HAF dan SRF. Pengaruh penambahan jumlah CB (jenis FEF) pada sifat swelling dan ketahanan pampat tetap pada karet SBR dan NBR dilaporkan oleh Mostafa, et.al. (2009). Bahan pengisi penguat (reinforcing) jarang digunakan secara tunggal dalam jumlah yang cukup besar karena dapat menyebabkan deteriorasi sifat mekanik yang disebabkan oleh sifat dispersi bahan pengisi yang buruk. Rattanasom et.al. (2007) menyatakan bahwa vulkanisat karet alam (NR) dengan bahan pengisi silika/CB dengan rasio 20/30 memberikan sifat mekanik yang lebih baik daripada hanya dengan bahan pengisi silika atau CB saja sebesar $50 \mathrm{phr}$.

Interaksi polimer dengan pelarut merupakan hal penting baik dari sudut pandang akademik maupun teknologi. Polimer yang terikat silang (crosslinking) bila kontak dengan pelarut akan menunjukkan fenomena swelling. Derajat swelling dinyatakan dalam jumlah cairan (liquid) yang diserap oleh polimer (Abu-Abdeen dan Elamer, 2010). Swelling vulkanisat karet merupakan proses difusi. Sejumlah pelarut akan mendifusi kedalam karet sampai mencapai kesetimbangan (equilibrium). Proses difusi tersebut merupakan parameter kinetis yang bergantung pada volume kosong pada bahan, mobilitas segmental rantai polimer dan ukuran molekul penetran. Bahan pengisi aktif yang terdapat dalam matriks polimer menurunkan koefisien difusivitas karena molekul penetran akan menempuh jalur yang lebih berliku (tortuous) dalam berpenetrasi kedalam badan polimer. Penyerapan pelarut dan difusinya merupakan faktor pembatas pada aplikasi polimer karena proses tersebut menyebabkan perubahan sifat mekanik bahkan dapat menyebabkan destruksi struktur polimer. Oleh karena itu karakteristik swelling dari sebuah polimer penting untuk dipelajari untuk efisiensi dan efektivitas aplikasinya (Stephen, et.al., 2007, Choi dan Ha, 2009 dan Unnikrishnan dan Thomas, 1995, A1 Minnath et.al., 2011).

Penelitian ini bertujuan untuk mempelajari pengaruh penambahan $\mathrm{CB}$ jenis HAF dan SRF dengan rasio tertentu terhadap karakteristik vulkanisasi, sifat morfologi, karakteristik swelling dan perpindahan massa pada vulkanisat NBR.

\section{BAHAN DAN METODE PENELITIAN}

\section{Bahan Penelitian}

Bahan penelitian terdiri atas karet NBR Krynac 4975 F (100 phr) dengan kadar acrylonitrile 48,5\%, viskositas Mooney (ML $\left.(1+4) 100^{\circ} \mathrm{C}\right) 75$, berat jenis $1,01 \mathrm{~g} / \mathrm{cm}^{3}$. Asam stearat $1 \mathrm{phr}$; zinc oxide $(\mathrm{ZnO}) 5 \mathrm{phr}$; HAF Black (N-330) 0 - 70 phr; SRF Black (N-774) $0-70 \mathrm{phr}$, OCI; dioctyl phthalate (DOP) 15 phr; 2,2,4,trimethyl-1,2, dihydroquinoline (TMQ) 2 phr, Kemai; paraffin wax Antilux 654 A, Rhein Chemie, buatan Germany 1 phr, mercaptobenzothiazole (MBTS) 2 phr, Shandong Sanxian, China; 
Tabel 1. Variasi formulasi kompon NBR

\begin{tabular}{lcccccccc}
\hline Bahan & \multicolumn{7}{c}{ Kode } \\
\cline { 2 - 9 } (phr) & P1 & P2 & P3 & P4 & P5 & P6 & P7 & P8 \\
\hline HAF & 0 & 10 & 20 & 30 & 35 & 40 & 50 & 70 \\
SRF & 70 & 60 & 50 & 40 & 35 & 30 & 20 & 0 \\
Belerang & 0,5 & 0,5 & 0,5 & 0,5 & 0,5 & 0,5 & 0,5 & 0,5 \\
\hline
\end{tabular}

tetramethylthiuramdisulphide (TMTD) 1,5 phr, Stairchem, China; Sulfur MIDAS SP 325 kemurnian 99\% variasi 0,5 - 1,5 phr, Miwon dan coumarone indene $(\mathrm{CI})$ resin $1 \mathrm{phr}$.

\section{Metode Penelitian}

\section{Preparasi Kompon NBR}

Kompon NBR dibuat dengan formulasi seperti disajikan pada Tabel 1. Pencampuran (mixing) semua komponen penyusun vulkanisat NBR, dilakukan dengan two roll mill skala laboratorium dengan rasio friksi $1,1: 1$, suhu rol berkisar $40-50^{\circ} \mathrm{C}$ dan waktu pencampuran 45-50 menit. Kompon dikondisikan selama 24 jam pada suhu $25^{\circ} \mathrm{C}$ kelembaban $60 \%$ sebelum divulkanisasi.

\section{Pengamatan Karateristik Vulkanisasi}

Karakteristik vulkanisasi meliputi torsi minimum $\left(\mathrm{M}_{\mathrm{L}}\right)$, torsi maksimum $\left(\mathrm{M}_{\mathrm{H}}\right)$, waktu $\operatorname{scorch}\left(\mathrm{t}_{\mathrm{s} 2}\right)$ dan waktu optimum vulkanisasi $\left(\mathrm{t}_{90}\right)$ diamati menggunakan Kunhwa Rheometer pada suhu $160^{\circ} \mathrm{C}$, sesuai dengan ASTM D 2084. Indeks kecepatan vulkanisasi (cure rate index/CRI) dihitung berdasarkan perbedaan waktu optimum dengan waktu scorch sesuai dengan persamaan (1).

$C R I=\frac{100}{t_{90}-t_{s 2}}$

\section{Pengujian Morfologi}

Morfologi vulkanisat dipelajari menggunakan alat Scanning Electron Microscophy (SEM) merek JEOL 330 dengan perbesaran 1000x. Potongan melintang vulkanisat diamati untuk mengetahui tingkat dispersi dan distribusi partikel $\mathrm{CB}$ didalam matriks karet NBR.

\section{KesetimbanganSwelling}

Pengamatan swelling dilakukan dengan cara perendaman sampel dalam benzen. Sampel vulkanisat NBR berukuran 20x20x2 $\mathrm{mm}$ divulkanisasi dengan cetak tekan menggunakan hidrolik pres pada suhu $160^{\circ} \mathrm{C}$ dan tekanan $150 \mathrm{~kg} / \mathrm{cm}^{2}$. Berat awal sampel $\left(\mathrm{W}_{0}\right)$ diukur, kemudian sampel direndam dalam benzen (dalam botol difusi) dengan massa molar $\mathrm{M}_{\mathrm{S}}$ pada suhu kamar. Secara periodik sampel diambil, sisa pelarut yang menempel pada permukaan sampel dibersihkan dengan kertas tisu. Sampel ditimbang dan diperoleh berat tertentu $\left(\mathrm{W}_{\mathrm{t}}\right)$, kemudian sampel dikembalikan kedalam botol. Pengamatan dilakukan sampai diperoleh berat sampel yang tetap $\left(\mathrm{W}_{1}\right)$. Jumlah pelarut yang diserap oleh vulkanisat pada waktu $\mathrm{t}\left(\mathrm{Q}_{\mathrm{t}}\right)$, dinyatakan dalam persamaan (2).

$Q_{t}=\frac{\frac{W_{o}-W_{1}}{M s}}{W_{o}} \times 100$

Jika $M_{s}$ adalah molaritas pelarut (Mathew, et.al., 2006; Dasan, et.al., 2008; Manoj, et.al., 2011).

\section{HASIL DAN PEMBAHASAN}

\section{Karakteristik Vulkanisasi}

Rheometer merupakan instrumen yang baik untuk mengevaluasi efek interaksi CB dengan karet pada kecepatan vulkanisasi dan pembentukan ikatan silang (crosslinking), dan tujuannya adalah untuk mengetahui parameter-parameter kritis yang terkait dengan proses vulkanisasi. Gambar 1 menunjukkan torsi minimum dan maksimum pada vulkanisat NBR. 


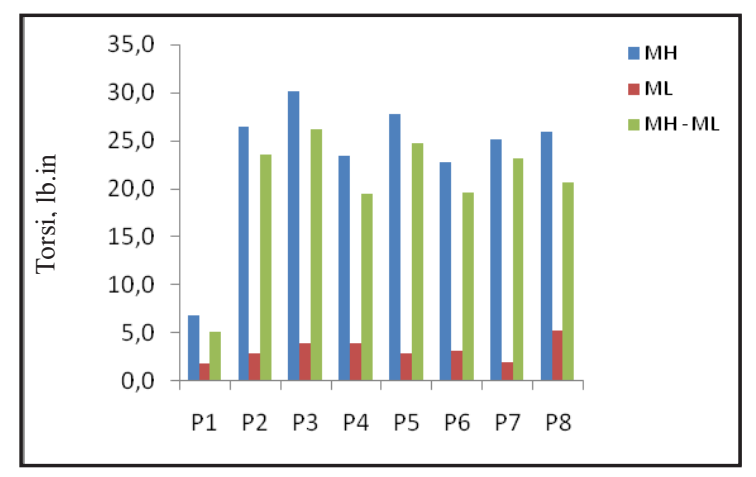

Gambar 1. Torsi minimum dan maksimum pada vulkanisat NBR

Torsi minimum $\left(\mathrm{M}_{\mathrm{L}}\right)$, adalah torsi lelehan karet yang belum tervulkanisasi pada $160^{\circ} \mathrm{C}$, dan $\mathrm{M}_{\mathrm{L}}$ merupakan indikator derajat pembentukan ikatan silang.Proses komponding NBR dengan CB selama periode waktu tertentu memberikan kesempatan pada rantai molekul NBR kontak dengan CB dan terperangkap didalam ruang kosong (void) dari agregat CB.Rantai molekul NBR menjadi tidak bebas bergerak (immobile) dan terlokalisasi. Pembentukan ikatan silang secara fisik menghambat mobilitas rantai molekul dan menahan deformasi karet. Menurut Li, et.al. (2008) dan Manoj, et.al. (2010) bahwa luas permukaan CB mempunyai peran penting untuk tingkat kerapatan ikatan silang yang terbentuk. Bila luas permukaan bertambah, maka jumlah rantai yang terperangkap pada agregat CB juga bertambah, demikian pula dengan ikatan silangnya. Gambar 1 menunujukkan P1 mempunyai $\mathrm{M}_{\mathrm{L}}$ lebih rendah daripada $\mathrm{P} 8$. Hal ini dapat dijelaskan bahwa HAF mempunyai luas permukaan yang lebih besar daripada SRF. Oleh karena itu, partikel HAF memberikan kemungkinan lebih besar bagi rantai molekul NBR untuk terperangkap dalam agregatnya. Vulkanisat dengan campuran HAF dan SRF (P2-P7) secara umum menunjukkan kecenderungan naik dan mencapai nilai maksimum pada P3, kemudian turun. Hal ini dapat dijelaskan bahwa pada P2 sampai dengan P3 HAF memberikan peran besar bagi terbentuknya ikatan silang secara fisik, yaitu dengan menyediakan luas permukaan yang besar. SRF meskipun mempunyai luas permukaan lebih kecil, namun dalam jumlah yang besar juga memberikan kontribusi yang penting bagi terbentuknya ikatan silang secara fisik. Bertambahnya jumlah HAF pada vulkanisat menyebabkan penurunan $\mathrm{M}_{\mathrm{L}}$. Meskipun luas permukaan yang disediakan HAF besar, namun pencampurannya lebih sulit dan besar kemungkinannya membentuk agregat sehingga dispersi dan distribusi partikel bahan pengisi yang homogen akan sulit dicapai (Jovanović, et.al., 2009). P5 memberikan nilai $\mathrm{M}_{\mathrm{L}}$ lebih rendah daripada $\mathrm{P} 4$ maupun $\mathrm{P} 6$.

Selama proses vulkanisasi berlangsung selain terbentuk ikatan silang secara fisik juga terbentuk ikatan silang secara kimiawi sebagai hasil reaksi antara molekul karet dengan beberapa reagensia vulkanisasi. Perbedaan torsi maksimum $\left(\mathrm{M}_{\mathrm{H}}\right)$ dan minimum $\left(\mathrm{M}_{\mathrm{L}}\right)$, yang disebut sebagai $\Delta \mathrm{M}$, merupakan indikator atau penunjuk derajat kerapatan ikatan silang kimiawi (Li, et.al., 2008; Jovanović, et.al., 2009; Rattanasom dan Prasertsri, 2009). Kerapatan ikatan silang yang terbentuk, seperti ditunjukkan Gambar 1. Secara umum terdapat kecenderungan naik sampai mencapai nilai maksimum (P3) dan kemudian turun lagi. Perbedaan $\mathrm{M}_{\mathrm{H}}$ dan $\Delta \mathrm{M}$ yang mencolok terlihat pada vulkanisat dengan bahan pengisi tunggal (P1 dan P8). HAF dengan ukuran partikel kecil memberikan nilai yang lebih tinggi daripada SRF dengan ukuran partikel yang lebih besar. Hal ini sesuai dengan penemuan Rattanasom dan Prasertsri (2009) yang menyebutkan bahwa ukuran partikel CB yang kecil memperlihatkan perbedaan torsi tinggi daripada partikel dengan ukuran besar. Pembentukan ikatan silang kimiawi tidak hanya dipengaruhi oleh reaksi kimia antara reagensia vulkanisasi dengan karet tetapi juga turut mempengaruhi adalah ikatan kimia antara karet dengan gugus fungsi pada permukaan carbon black. Sulfur yang pada permukaan carbon black turut meningkatkan vulkanisasi (Li, et.al., 2008; Manoj, et.al., 2010). SRF dilaporkan oleh Li, et.al. (2008) tidak mempunyai gugus sulfur pada permukaan partikelnya, sehingga $\mathrm{M}_{\mathrm{H}}$ dan $\Delta \mathrm{M}$ nya yang lebih rendah daripada HAF yang ditambah. Hal ini dapat dijelaskan perbedaan $\mathrm{MH}$ pada saat digunakan bahan pengisi tunggal. Waktu scorch $\left(\mathrm{t}_{\mathrm{s} 2}\right)$, optimum vulkanisasi $90 \%\left(\mathrm{t}_{90}\right)$ dan indeks kecepatan 
Tabel 2. Karakteristik vulkanisasi

\begin{tabular}{cccc}
\hline Kode & $\mathrm{t}_{\mathrm{S} 2}$, det & $\mathrm{t}_{90}$, det & CRI, det $^{-1}$ \\
\hline P1 & 295 & 615 & 0,31 \\
P2 & 109 & 286 & 0,56 \\
P3 & 100 & 250 & 0,67 \\
P4 & 114 & 272 & 0,63 \\
P5 & 133 & 347 & 0,47 \\
P6 & 122 & 349 & 0,44 \\
P7 & 112 & 272 & 0,63 \\
P8 & 105 & 289 & 0,54 \\
\hline
\end{tabular}

reaksi vulkanisasi (Cure Rate Index/CRI) ditunjukkan oleh Tabel 2.

Waktu scorch merupakan indikator keamanan olah (scorch safety), dan meningkat dengan naiknya waktu scorch. P1 memberikan $\mathrm{t}_{\mathrm{s} 2}$ tertinggi, sehingga memberikan keamanan olah yang lebih tinggi. Pada bahan pengisi ganda (P2-P7), secara umum $t_{\mathrm{s} 2}$ dan $t_{90}$ naik, mencapai nilai maksimum pada P6 dan kemudian turun lagi.Kecenderungan yang sama juga ditunjukkan oleh nilai $t_{90}$. Indeks kecepatan reaksi vulkanisasi merupakan pengukuran kecepatan reaksi vulkanisasi berdasarkan pada perbedaan waktu vulkanisasi optimum dan waktu scorch, saat vulkanisasi dimulai. Makin tinggi CRI maka makin tinggi pula kecepatan vulkanisasi (Al Minath et.al., 2011).Nilai CRI maksimum dijumpai pada P3, dengan demikian reaksi vulkanisasi pada sistem P3 berlangsung paling cepat dan baik.

\section{Sifat Morfologi Vulkanisat}

Morfologi vulkanisat NBR diamati menggunakan metode Scanning Electron Microscopy (SEM) dengan perbesaran 1000x, dan fotonya seperti tersaji pada Gambar 2.

Gambar 2a dan b menunjukkan morfologi vulkanisat yang menggunakan bahan pengisi tunggal, yaitu hanya HAF (P8) atau SRF (P1). P1 terlihat lebih homogen dibanding P8. Hal ini dapat dijelaskan bahwa partikel HAF mempunyai ukuran lebih kecil daripada SRF, sehingga dalam proses pencampuran dengan two roll mill akan lebih sulit terdistribusi secara homogen. Morfologi vulkanisat dengan bahan pengisi ganda (campuran antara HAF dan SRF) ditunjukkan
Gambar 2c dan d, dan terlihat bahwa P2 lebih homogen bila dibanding pada P6. Jumlah HAF pada $\mathrm{P} 2$ lebih sedikit bila dibanding pada P6 sehingga dalam proses pencampuran akan lebih mudah diperoleh dispersi bahan pengisi yang homogen.

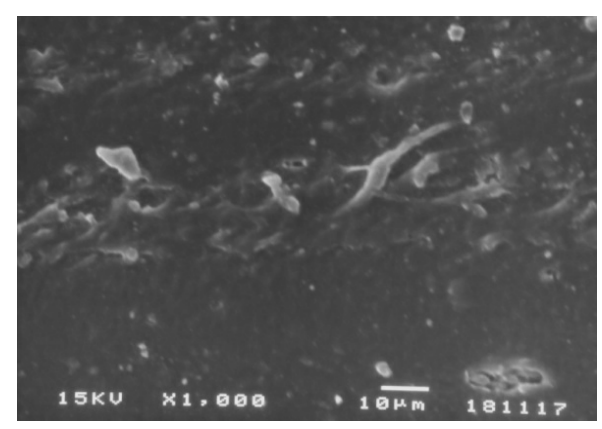

(a)

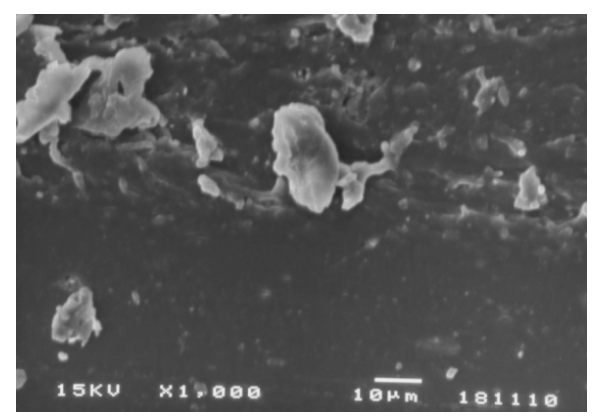

(b)

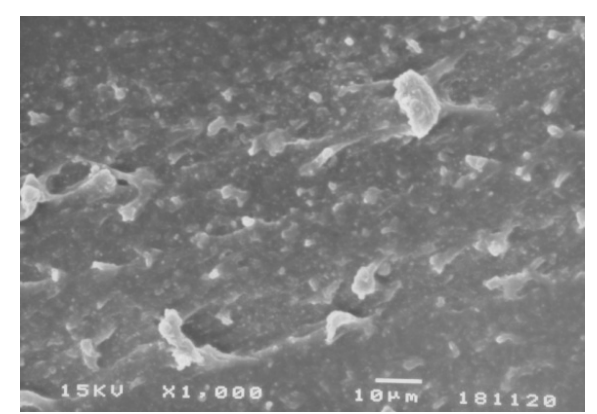

(c)

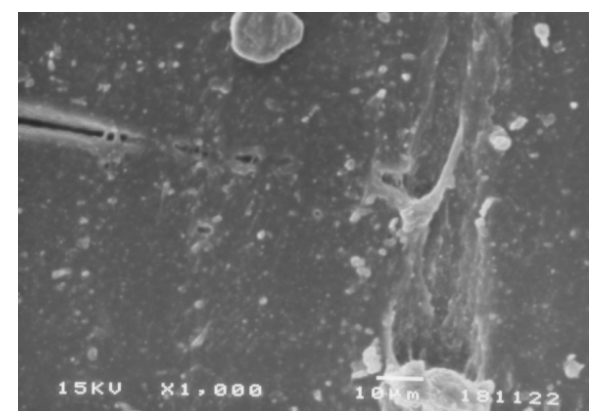

(d)

Gambar 2. Foto SEM vulkanisat NBR, (a) P1; (b) P8; (c) P2 dan (d) P6 


\section{Kesetimbangan Swelling}

Swelling pada vulkanisat dengan bahan pengisi CB terjadi karena keberadaan tekanan antara jaringan (network) karet dengan pelarut yang bekerja untuk mengembangkan (swell) atau mengerutkan (shrink) jaringan tersebut. Swelling terjadi karena ekspansi polimer dan tersedianya free volume yang lebih banyak untuk memfasilitasi perpindahan massa pelarut. Teori free volume menjelaskan bahwa proses difusi atau migrasi diatur oleh jumlah free volume dan ukuran molekul zat yang bermigrasi (Cassidy dan Aminabhavi, 1985).

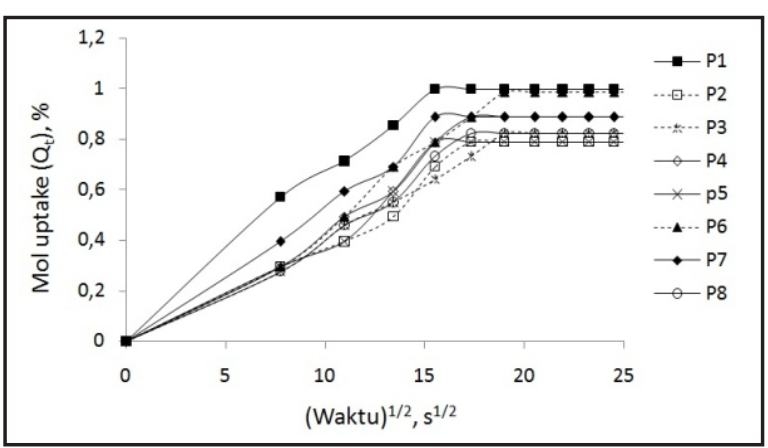

Gambar 3. Mol uptake pelarut pada variasi rasio $\mathrm{HAF} / \mathrm{SRF}$

Pola serapan benzen oleh vulkanisat NBR seperti yang ditunjukkan Gambar 3 secara umum memiliki kecenderungan yang sama hanya berbeda tingkat serapannya.

Pola serapan pada Gambar 3 terbagi atas 2 (dua) zona. Zona pertama merupakan uptake pelarut pada awal perendaman. Kecepatan swelling sangat tinggi pada daerah ini karena gradien konsentrasi yang cukup besar dan pelarut stress yang sangat kuat bekerja pada sampel polimer, dan kondisi demikian ditunjukkan oleh kenaikan kurva. Zona kedua diindikasikan dengan berkurangnya kecepatan swelling karena turunnya gradien konsentrasi dan pada akhirnya mencapai kesetimbangan. Hal ini berarti gradien konsentrasi mencapai nol (Stephen et. al., 2006). Kesetimbangan lokal tersebut diasumsikan terjadi pada seluruh titik selama proses difusi dan ekivalen dengan swollen state. Mostafa et. al. (2009) melaporkan tren yang sama, menggunakan karet NBR dengan N-550 sebagai bahan pengisi, bahkan P1 memberikan uptake pelarut tertinggi untuk bahan pengisi tunggal, dan uptake pelarut P1 lebih besar daripada P8. Kondisi ini berkaitan dengan kerapatan ikatan silang (ditunjukkan oleh $\Delta \mathrm{M}$ nya seperti ditunjukkan olehTabel 3), sedangkan P8 memberikan $\Delta \mathrm{M}$ lebih tinggi dibanding P1.Vulkanisasi menghambat pergerakan rantai molekul secara makro, tetapi menyisakan pergerakan lokal segemental yang tinggi. Penambahan CB dapat memodifikasi kondisi tersebut. Melalui proses wetting pada saat pencampuran two roll mill terjadi penempelan rantai molekul karet pada permukaan CB. Segmen-segmen polimer dibasahi (wet) dengan adsorpsi secara bertingkat permukaan partikel $\mathrm{CB}$ terhadap rantai molekul karet. Penguatan (reinforcement) oleh $\mathrm{CB}$ menghambat pergerakan lokal yang bebas rantai karet makromolekul dan oleh karenanya meningkatkan ketahanan terhadap pelarut. Carbon black (CB) meningkatkan kerapatan ikatan silang, sehingga meningkatkan kontribusi elastisitas terhadap jaringan. Ikatan silang tersebut menghambat daya mulur rantai karet yang diinduksi oleh swelling, akibatnya difusi pelarut ke dalam celah (gap) diantara molekul karet menjadi sulit, sehingga menurunkan persentase swelling dan mencegah terjadinya pemutusan rantai. Oleh karena itu, swelling dapat dikurangi dengan meningkatkan jaringan molekul karet (Mostafa, et. al., 2009; Lu, et. al., 2009; Manoj, et. al., 2011).

\section{Mekanisme Perpindahan}

Difusi pelarut terkait dengan sifat fisik jaringan polimer dan interaksi antara polimer dengan pelarut tersebut. Alfrey et. al. dalam Masaro and $\mathrm{Zu}$ (1999) mengklasifikasikan difusi berdasarkan kecepatan difusi pelarut dan kecepatan relaksasi polimer kedalam 2 (dua) jenis, yaitu Fickian (kasus I) dan NonFickian (kasus II dan anomali). Jumlah pelarut yang diserap per satuan luas unit polimer pada waktu $t$ didefiniskan pada persamaan 3 (Stephen et. al., 2007, Al Minnath, et. al., 2011).

$$
\log \left(\frac{Q t}{Q_{\infty}}\right)=\log k+n \log t
$$


Jika $Q_{t}$ dan $Q_{\infty}$ adalah mol \% uptake pada waktu $t$ dan waktu kesetimbangan, $k$ merupakan konstanta yang bergantung pada karakteristik struktural polimer dan memberikan informasi mengenai interaksi antara polimer dengan pelarut, dan $n$ adalah parameter yang berkaitan dengan mekanisme difusi, dan nilai $n$ berkisar antara $0,5-1$. Tipe Fickian (kasus I) mempunyai nilai $n=0,5$, dimana kecepatan relaksasi rantai polimer lebih tinggi dibanding dengan kecepatan difusi dari penetran. Tipe non-Fickian terdapat 2 (dua) jenis, yaitu kasus II dan anomali. Kasus II mempunyai kecepatan difusi yang lebih cepat daripada kecepatan relaksasi, sedangkan pada anomali kecepatan difusi dan relaksasi mempunyai orde yang sama. Nilai $n=1$ mengindikasikan perpindahan mendekati tipe non-Fickian (Kasus II), dimana kecepatan relaksasi rantai polimer lebih rendah daripada difusi cairan. Nilai $n$ antara $0,5-1$ mengindikasikan anomali perpindahan (Masaro dan Zu, 1999).

Nilai $k$ dan $n$ untuk vulkanisat dengan berbagai rasio $\mathrm{HAF} / \mathrm{SRF}$ diperoleh dengan analisa regresi dengan memplotkan log $\left(Q_{t} / Q_{\infty}\right)$ versus $\log t$, dan hasilnya disajikan pada Tabel 3 .

Nilai $n \mathrm{P} 1$ hingga $\mathrm{P} 8$ memberikan harga diatas 0,5 yang berarti mekanisme perpindahan pada vulkanisat tersebut diklasifikasikan sebagai anomali.

Tabel 3. Nilai $n$ dan $k$ vulkanisat NBR dengan berbagai rasio HAF/SRF

\begin{tabular}{ccc}
\hline Kode & $N$ & $k\left(\mathrm{~g} / \mathrm{g} \mathrm{det}^{\mathrm{n}}\right)$ \\
\hline P1 & 0,80 & 0,30 \\
P2 & 0,62 & 0,20 \\
P3 & 0,58 & 0,17 \\
P4 & 0,68 & 0,23 \\
P5 & 0,70 & 0,23 \\
P6 & 0,67 & 0,23 \\
P7 & 0,56 & 0,13 \\
P8 & 0,64 & 0,21 \\
\hline
\end{tabular}

Pada kondisi ini kecepatan difusi dan relaksasi segmen polimer adalah sebanding. Penyimpangan dari tipe Fickian diasosiasikan dengan waktu yang dibutuhkan oleh segmen karet untuk merespon swelling stress dan menata ulang kembali untuk mengakomodasi molekul pelarut. Penguatan oleh partikel bahan pengisi memberikan pembatasan dengan derajat yang tinggi terhadap proses penataan ulang rantai molekul karet. Nilai $k$ yang diberikan P1 merupakan nilai yang paling maksimum, sedanngkan nilai paling minimum diberikan oleh P7. Sedangkan vulkanisat lainnya memberikan nilai yang hampir sama, sehingga dapat dikatakan interaksi pelarut dengan polimernya relatif sama.

\section{Parameter Kinetika}

Proses difusi merupakan parameter kinetik yang berhubungan dengan ukuran penetran dan mobilitas segmen polimer. Koefisien difusi sampel polimer yang direndam dalam pelarut tertentu dihitung menggunakan persamaan (4).

$$
\frac{Q t}{Q_{\infty}}=1-\left(\frac{8}{\pi^{2}}\right) \sum_{n=0}^{n=\infty}\left[\frac{1}{(2 n+1)^{2}} \exp \left[-D(2 n+1)^{2} \pi^{2} \frac{t}{h^{2}}\right]\right]
$$

Jika $t$ adalah waktu, $h$ adalah ketebalan awal sampel, $D$ adalah koefisien difusi dan $\mathrm{n}$ merupakan integer. Dari persamaan tersebut dapat dilihat bahwa plot $Q_{t}$ versus $t^{1 / 2}$ adalah linier untuk waktu yang pendek dan $D$ dapat dihitung dari slope awal, sehingga persamaan (4) menjadi persamaan (5).

$$
\frac{Q t}{Q_{\infty}}=\frac{4}{\pi}\left(\frac{D}{h}\right) t^{1 / 2}
$$

Koefisien difusi dapat dihitung dengan memanipulasi persamaan (5) menjadi persamaan (6).

$$
D=\pi\left(\frac{h \theta}{4 Q_{\infty}}\right)^{2}
$$

Jika $\theta$ adalah slope awal pada plot $Q_{t}$ versus $t^{1 / 2}$ dan $Q_{\infty}$ merupakan persen mol uptake pada kesetimbangan (Stephen et. al., 2007). Persamaan (6) digunakan untuk sistem tanpa swelling yang kentara. Jika swelling 
diperhitungkan maka perlu koreksi terhadap swelling polimer dengan cara memasukkan $\varphi$, faksi volum polimer pada massa swollen, oleh karena itu memberikan nilai koefisien difusi intrinsik $D^{*}$ seperti pada persamaan (7).

$$
D=\frac{D}{\varphi^{\frac{7}{3}}}
$$

Fraksi volum polimer, $\varphi$, pada massa swollen dihitung menggunakan persamaan (8).

$\varphi=\frac{w_{1} / \rho_{1}}{w_{1} / \rho_{1}+w_{2} / \rho_{2}}$

Jika $w_{l}$ dan $\rho_{l}$ adalah berat dan densitas sampel polimer, sedangkan $w_{2}$ dan $\rho_{2}$ adalah berat dan densitas pelarut(Al Minnath et. al., 2011). Koefisien difusi intrinsik disajikan pada Tabel 4.

Menurut teori free volume untuk proses difusi pada polimer, kecepatan difusi sebuah molekul tergantung terutama pada mudah atau tidaknya segmen polimer bertukar posisi dengan molekul penetran. Sebagai tambahan, mobilitas polimer tergantung pada jumlah free volume di dalam matrik (Gambar 4). Bahan pengisi akan mengisi free volume dan membentuk jalur yang berliku (turtuous path) bagi molekul penentran. Derajat jalur berliku ini dipengaruhi oleh fraksi volume, bentuk serta orientasi bahan pengisi (George and Thomas, 2001).

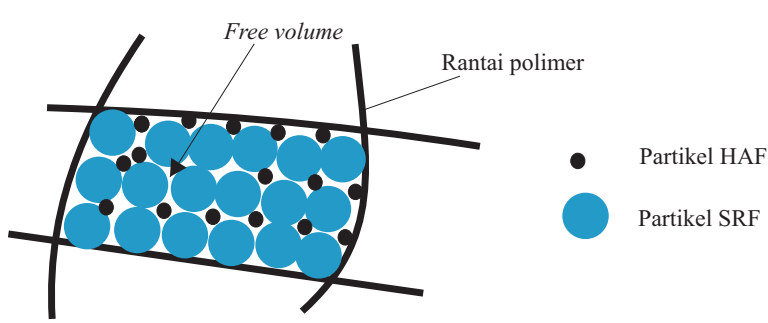

Gambar 4. Ilustrasi free volume dalam matriks NBR

Jika jumlah free volume dalam matriks polimer kecil, maka mobilitas rantai polimer akan rendah. Sehingga kecepatan difusi molekul penetran kedalam matriks polimer akan rendah pula. P1 mempunyai koefisien difusi intrinsik yang lebih besar dibanding P8. Free volume yang diberikan oleh SRF lebih besar daripada oleh HAF karena perbedaan ukuran partikel. Vulkanisat dengan bahan pengisi $\mathrm{HAF} / \mathrm{SRF}$ diharapkan mampu memberikan jumlah free volume yang rendah. Namun, dispersi bahan pengisi di dalam matriks polimer juga turut mempengaruhi jumlah free volume. Bila dispersi bahan pengisi di dalam matriks buruk, maka akan timbul ruang kosong (void) pada lapisan antara (interface) yang akan mendorong naiknya jumlah free volume.

Tabel 4. Parameter kinetika difusi

\begin{tabular}{cccc}
\hline Kode & $D^{*}\left(10^{2} \mathrm{~cm}^{2} / \mathrm{s}\right)$ & $S$ & $P\left(10^{2} \mathrm{~cm}^{2} / \mathrm{s}\right)$ \\
\hline P1 & 7,29 & 0,78 & 5,67 \\
P2 & 3,28 & 0,62 & 2,02 \\
P3 & 3,91 & 0,64 & 2,52 \\
P4 & 5,03 & 0,70 & 3,48 \\
P5 & 6,72 & 0,62 & 4,14 \\
P6 & 3,99 & 0,69 & 2,76 \\
P7 & 3,40 & 0,69 & 2,35 \\
P8 & 4,87 & 0,64 & 3,13 \\
\hline
\end{tabular}

Koefisien difusi intrinsik, $D^{*}$, pada Tabel 4 menunjukkan bahwa vulkanisat dengan rasio HAF/SRF 0/70 (P1) memberikan $D^{*}$ paling tinggi, sedangkan $\mathrm{P} 8$, dimana rasio $\mathrm{HAF} / \mathrm{SRF} 70 / 0$, mempunyai harga $D^{*}$ yang lebih rendah daripada $\mathrm{P} 1$. Teori free volume diatas dapat menjelaskan alasan untuk kondisi tersebut. SRF memiliki ukuran partikel yang lebih besar bila dibanding HAF, oleh karena itu akan memberikan free volume yang lebih banyak. Konsekuensinya akan meningkatkan difusivitas molekul penetran kedalam matriks NBR. Vulkanisat dengan bahan pengisi ganda relatif memberikan nilai $D^{*}$ lebih rendah daripada P8, kecuali untuk P4 dan P5. Pada kedua vulkanisat tersebut fraksi volume HAF dan SRF didalam matriks NBR hampir sama. Fraksi HAF yang besar akan memberikan 
dispersi yang kurang baik seperti yang ditunjukkan oleh Gambar 2d. Akibatnya $D^{*}$ naik karena jumlah free volume dalam matriks NBR meningkat, sedangkan P2, P3, P6 dan P7 memberikan $D^{*}$ lebih rendah daripada vulkanisat lainnya karena fraksi HAF dan SRF dalam matriks mampu memberikan jumlah free volume yang rendah, sehingga meningkatkan derajat jalur liku (turtuosity) bagi molekul penetran untuk berpenetrasi kedalam matriks NBR. Nilai $D^{*}$ yang rendah menunjukkan interaksi NBR dengan $\mathrm{CB}$ dalam matriks relatif tinggi.

Permeasi molekul penetran kedalam polimer tidak hanya bergantung pada difusivitas, tetapi juga pada solubilitas atau kemampuan menyerap (sorption) dari penetran. Koefisien serapan, $S$, yang berkaitan dengan kesetimbangan serapan maksimum penentran dihitung menggunakan persamaan (9).

$S=\frac{M_{\infty}}{M_{p}}$

Jika $M_{\infty}$ adalah massa pelarut pada kesetimbangan swelling dan $M_{p}$ adalah massa awal sampel polimer. Tabel 4 menyajikan koefisien serapan $\mathrm{S}$ untuk vulkanisat NBR pada berbagai rasio HAF/SRF. Nilai $S$ maksimum diberikan oleh $\mathrm{P} 1$, yang berarti bahwa massa pelarut diakomodasi paling baik pada sistem P1. Hal ini terkait dengan jumlah Free volume yang tersedia pada sistem tersebut.

Proses permeasi merupakan kombinasi proses penyerapan dan difusi, dan oleh karena itu tergantung pada koefisien penyerapan $(S)$ dan difusinya $\left(D^{*}\right)$. Koefisien permeasi dihitung dengan persamaan (10).

$P=D^{*} S$

Secara lengkap nilai $P$ disajikan pada Tabel 4, jika nilai $P$ maksimum diberikan oleh P1. Secara umum nilai $P$ vulkanisat NBR pada berbagai rasio $\mathrm{HAF} / \mathrm{SRF}$ menunjukkan tren yang sama dengan $D^{*}$.

\section{KESIMPULAN}

Karakteristik vulkanisasi vulkanisat dengan bahan pengisi ganda HAF dan SRF menunjukkan dampak positif daripada dengan bahan pengisi tunggal yaitu HAF atau SRF saja. Kerapatan ikatan silang yang diwakili oleh $\Delta \mathrm{M}$, maksimum pada $\mathrm{P} 3$, demikian pula dengan CRI. Kesetimbangan swelling memberikan gambaran mengenai banyaknya pelarut yang diserap (uptake) oleh vulkanisat. Serapan maksimum terjadi pada P1. Mekanisme perpindahan massa vulkanisat NBR diklasifikasikan sebagai perpindahan anomalus dengan nilai $n>0,5$ pada semua rasio $\mathrm{HAF} / \mathrm{SRF}$, sedangkan konstanta $k$ mempunyai nilai yang relatif sama. Nilai $D^{*}, \mathrm{~S}$ dan $\mathrm{P}$ menunjukkan tren yang sama, dan nilai maksimum dijumpai pada $\mathrm{P} 1$.

\section{DAFTAR PUSTAKA}

Al Minnath, M., Unnikrishnan, G. and Purushothaman, E., 2011. Transport studies of thermoplastic polyurethane/natural rubber (TPU/NR) blends, J. Membrane Sci. 379:361-369.

Barlow, F. W., 1993.Rubber Compounding: Principles, Materials and Techniques, 2nd Ed., Marcel Dekker, Inc., New York

Cassidy, P. E. and Aminabhavi, T. M., 1985. Water permeation through elastomer laminates: 3. Neoprene/styrenebutadiene rubber, Polymer 27:13961399.

Choi, S. and Ha, S., 2009, Influence of the swelling temperature and acrylonitrile content of NBR on the water swelling behaviors of silica-filled NBR vulcanizates, J. Ind. Eng. Chem. 15 : 167-170.

Dasan, K. P., Unnikrishnan, G. and Purushothaman, E., 2008.Pelarutt transport through carbon black filled poly(ethylene-co-vinyl acetate) composites, eXPRESS Polymer Letter 2 (5) : 382-390.

Franta, I., Vondracek, P., Meissner, B. and Duchacek, V., 1989. Compounding Materials and Special Purpose Additives, in I. Franta (Ed.), Elastomers and Rubber Compounding Materials, STNL-Publisher of Technical 
Literature, Prague.

Jovanović, V., Simendic, J. B., Jovanovic, S. S., Markovic, G. and Milena, M. C., 2009. The influence of carbon black on curing kinetics and thermal aging of acrylonitrile-butadiene rubber, CI\&CEQ 15(4): 283-289.

Li, Z. H., Zhang, J. and Chen, S. J., 2008. Effect of carbon blacks with various structures on vulcanization and reinforcement of filled ethylenepropylene-diene rubber, eXPRESS Polymer Letter 2(10): 695-704.

Lu, Y., Zhang, J., Chang, P., Quan, Y. And Chen, Q., 2010, Effect of filler on compression set, compression stressstrain behaviour, and mechanical properties of polysulfide sealants, $J$. Appl. Polym Sci 120: 2001-2007.

Abu-Abdeen, M. and Elamer, I., 2010. Mechanical and swelling properties of thermoplastic elastomer blends, Mat. Des. $31: 808-815$.

Masaro, L. and Zu, X. X., 1999. Physical models of diffusion for polymer solutions, gels and solids, Prog. Polym. Sci. 24 : 731-775.

Mathew, L., Joseph, K. U. and Joseph, R., 2006. Swelling behaviour of isora/natural rubber composites in oils used in automobiles, Bull. Mater. Sci. 29 (1) : 91-99.

Manoj, K. C., Kumari, P., Unnikrishnan, G., 2011. Cure Properties, swelling behaviors and mechanical properties of carbon black filler reinforced EPDM/NBR blend system, J. Appl. Polym. Sci., $120: 2654-2662$.
Mostafa, A., Aboel-Kasem, A., Bayoumi, M. R. and El-Sebaie, 2009. Effect of carbon black loading on the swelling and compression set behavior of SBR and NBR rubber compound, J. Mater. Des. $30: 1561-1568$.

Mostafa, A., Aboel-Kasem, A., Bayoumi, M.R. and El-Sebaie, 2009. Insight into the effect of $\mathrm{CB}$ loading on tension, compression, hardness and abrasion properties of SBR and NBR filled compounds, J. Mater. Des. 30 : 17851791.

Stephen, R., Joseph, K., Oomen, Z. and Thomas, S, 2007. Molecular transport of aromatic pelarutts through microcomposites of natural rubber and carboxylated styrene butadiene rubber (XSBR) and their blends, Composites Sci.Tech. 67: 1187-1194.

Rattanasom, N., Saowapark, T. and Deeprasertkul, C., 2007. Reinforcement of natural rubber with silica/carbon black hybrid filler, Polym. Test. $26: 369$.

Rattanasom, N. and Prasertsri, S., 2009. Relationship among mechanical properties, heat ageing resistance, cut growth behaviour and morphology in natural rubber: Partial replacement of clay with various types of carbon black at similar hardness level, Polym. Test. $28: 270-276$.

Unnikrishnan, G. and Sabu, T. 1995. Sorption and diffusion of aromatic hydrocarbons through filled natural rubber, Polymer 37 (13) : 2687-2693. 